Diplopora cincta, Hutton, but its precise place I am unable to discuss at present.

The following table shows the arrangement of the Steganoporellidæ which I propose :-

\title{
Family Steganoporellidæ.
}

\section{Genus Smittipora, Jullien.}

Zocecia with the lower compartment (situated beneath the calcareous lamina) undivided.

Type: S. abyssicola, Smitt.

\section{Genus Steganoporella, Smitt (part.).}

Zoceia with the aboral compartment divided into two chambers by a diaphragm, the lower of which is connected by a tubular passage with the upper and contains the polypide ; the whole of the upper half of the cell forming a large cavity, closed in by the operculum and membranous front wall. Operculum very large. External oœcia wanting; represented by an internal chamber.

Type: S. magnilabris, Busk.

\section{Genus Thalamoporella, n. gen.}

Zoceia with the lower compartment divided; from the centre of the anterior extremity of the lamina a narrow calcareous wall is carried up to a level with the margin of the cell, to which it is united, forming an orifice, which is partially closed by the operculum; on each side of it a large foramen. Operculum small, semicircular. Oxcia external, bilobate.

Type: T. Rozieri, Andouin.

\section{MISCELLANEOUS.}

On the Class Podostomata, a Group embracing the Merostomata and Trilobites. By A. S. PACKard.

Is a paper read in November 1885 before the National Academy of Sciences we have endeavoured, by giving the history of the Xiphosura, Pœcilopoda, and Gigantostraca, to show that while the name Xiphosura should be retained for the suborder of which Limulus is the type, the names Pœcilopoda and Gigantostraca have been applied in such different senses that they cannot well be retained for the Merostomata and Trilobita taken together in the sense we advocate. We have therefore proposed the term Podostomata for this class of Arthropoda. It is derived from $\pi \omega \hat{v} s, \pi o \delta$ òs, foot, and rтí $\mu$, mouth, in allusion to the foot-like or ambulatory 
nature of the cephalic appendages which surround the mouth in a manner characteristic of the group.

The class Podostomata may be defined as a group of marine Arthropods in which the cephalic (Limulus) or cephalothoracic (Trilobites) appendages are in the form of legs, $i . e$. ambulatory appendages, usually ending in forceps or larger claws (chelæ), which in the sole living representative of the class are arranged in an incomplete circle around the mouth; the basal joint of each leg is spiny, so as to aid in the retention and partial mastication of the food. No functional antennæ, mandibles, or maxillæ. Eyes both compound and simple. Respiration by branchiæ attached to the abdominal appendages, which are broad and lamellate in Merostomata, and cylindrical, with narrow gills, in Trilobita. The brain supplying nerves to the eyes alone; the nerves to the cephalic or cephalothoracic appendages originating from an œsophageal ring; the ventral cord ensheathed by a ventral arterial system more perfectly developed than in insects or scorpions. Coxal glands highly developed, with no external opening in the adult. The class differs from the Arachnida, among other characters, in having no functional cheliceres ("mandibles") or pedipalps ("maxillæ"); in the cephalic appendages either ending in larger claws or forceps, or in being simple, the terminal joint not bearing a pair of minute claws or ungues like those of Arachnida and Insecta, enabling their possessors to climb as well as walk. Podostomata have no urinary tubes. Limulus undergoes a slight metamorphosis, while in Trilobites the adult differs from the larva in having a greater number of thoracic segments.

From the Crustacea the Podostomata differ in the lack of functional antennæ and mouth-parts, in the compound eyes having no rods or cones, in the brain innervating the eyes (compound and simple) alone, in the shape of the head and pygidium or abdominal shield, and in the arterial coat completely enveloping the central nervous cord.

The Podostomata are divided into two orders :-

$$
\text { I. Merostomata, with three suborders : }\left\{\begin{array}{l}
\text { Xiphosura. } \\
\text { Synxiphosura. } \\
\text { Eurypterida. }
\end{array}\right.
$$

II. Trilobita.

\section{On the Anatomy and Classification of the Phytopti. By Dr. Alfred Nalepa.}

The cephalothorax of the Gall-mites is unusually reduced, the abdomen, on the contrary, considerably extended and annulated. Besides the organs of the mouth the former bears only two distinctly quinquearticulate pairs of legs. The mouth-organs have the form of a more or less strongly bent rostrum. The stilettiform cheliceræ lie in a sucking-tube formed by the maxillæ, which is supported by the labium. The maxillary palpi are four-jointed, only the basal joint is amalgamated with the maxilla. At the extremity of the abdomen on each side of the anus there are two semilunar retrac- 


\section{$2 \mathrm{BHL}$ Biodiversity Heritage Library}

Packard, A. S. 1887. "On the class Podostomata, a group embracing the Merostomata and Trilobites." The Annals and magazine of natural history; zoology, botany, and geology 19, 164-165. https://doi.org/10.1080/00222938709460216.

View This Item Online: $\underline{\text { https://www.biodiversitylibrary.org/item/55145 }}$

DOI: https://doi.org/10.1080/00222938709460216

Permalink: $\underline{\text { https://www.biodiversitylibrary.org/partpdf/56985 }}$

\section{Holding Institution}

Smithsonian Libraries

\section{Sponsored by}

Smithsonian

\section{Copyright \& Reuse}

Copyright Status: Public domain. The BHL considers that this work is no longer under copyright protection.

This document was created from content at the Biodiversity Heritage Library, the world's largest open access digital library for biodiversity literature and archives. Visit BHL at https://www.biodiversitylibrary.org. 